\title{
Article \\ In Vitro Biocompatibility of Several Children's Toothpastes on Human Gingival Fibroblasts
}

\author{
María Pilar Pecci-Lloret ${ }^{1}\left(\right.$ , Sergio López-García ${ }^{2,3}$, Francisco Javier Rodríguez-Lozano ${ }^{1,3, *(\mathbb{D} \text {, }}$ \\ Pablo Álvarez-Novoa ${ }^{4}$ and David García-Bernal ${ }^{3,5}$ [D
}

1 Gerodontology and Special Care Dentistry Unit, Morales Meseguer Hospital, Faculty of Medicine, University of Murcia, 30100 Murcia, Spain; mariapilar.pecci@um.es

2 Department of Stomatology, Faculty of Medicine and Dentistry, Universitat de Valencia, 46010 Valencia, Spain; sergio.lopez-garcia@uv.es

3 Cellular Therapy and Hematopoietic Transplant Group, Instituto Murciano de Investigación Biosanitaria Virgen de la Arrixaca, University of Murcia, 30120 Murcia, Spain; david.garcia23@um.es

4 Department of Surgery and Medical-Surgical Specialties, School of Medicine and Dentistry, Universidade de Santiago de Compostela, 15705 La Coruña, Spain; pablo.alvarez@rai.usc.es

5 Biochemistry, Molecular Biology and Immunology Department, Faculty of Medicine, University of Murcia, 30100 Murcia, Spain

* Correspondence: fcojavier@um.es

check for updates

Citation: Pecci-Lloret, M.P.;

López-García, S.; Rodríguez-Lozano, F.J.; Álvarez-Novoa, P.; García-Bernal, D. In Vitro Biocompatibility of Several Children's Toothpastes on Human Gingival Fibroblasts. Int. J. Environ. Res. Public Health 2022, 19, 2954. https://doi.org/10.3390/ ijerph19052954

Academic Editor: Paul B. Tchounwou

Received: 11 February 2022

Accepted: 1 March 2022

Published: 3 March 2022

Publisher's Note: MDPI stays neutral with regard to jurisdictional claims in published maps and institutional affiliations.

Copyright: (C) 2022 by the authors. Licensee MDPI, Basel, Switzerland. This article is an open access article distributed under the terms and conditions of the Creative Commons Attribution (CC BY) license (https:// creativecommons.org/licenses/by/ $4.0 /)$.

\begin{abstract}
The European Academy of Paediatric Dentistry has recommended fluoride toothpastes from the eruption of the first teeth in children. Toothpastes stay in the mouth in contact with human gingival fibroblasts (hGFs) for a long time. Thus, the objective of this study was to compare the cytotoxicity of five different commonly used children's toothpastes: Oral B Kids +3 (Procter \& Gamble, Alicante, Spain), Fluor Kin Calcium (Kin, Madrid, Spain), PHB Junior (PHB, Barcelona, Spain), Colgate +3 (Colgate Palmolive, Madrid, Spain) and Vitis Kids (Dentaid, Valencia, Spain) on hGFs. The children's toothpastes were exposed to hGFs at different concentrations (1:1, 1:2, 1:4). Afterwards, several tests were performed: MTT assays, cell cycle analyses, cell cytoskeleton staining assays, apoptosis/necrosis assays, and ICP-MS and ion chromatography. Oral B displayed the lowest cytotoxicity and was the toothpaste with the highest fluoride ion release; meanwhile, the other toothpastes were cytotoxic $\left.{ }^{* * *} p<0.0001\right)$; Fluor Kin being the one with the lowest fluoride ion release. Among all the toothpastes analyzed, Oral B exhibited the best results in vitro in terms of biocompatibility. Future evaluations, both in vitro and in vivo, are required to confirm the biocompatibility of sodium lauryl sarcosinate and sodium lauryl sulfate containing toothpastes.
\end{abstract}

Keywords: children's toothpastes; biocompatibility; SLS; fluoride

\section{Introduction}

Caries is a preventable disease, and one of the groups most affected by this disease are children [1,2]. Early childhood caries has a prevalence of $48 \%$, which has not changed in the last thirty years [3].

Caries prevention starts at home; it is known that dietary sugar exposure should be avoided or reduced [4]. In addition, another essential factor that influences caries prevention is the self-application of fluoride in the form of toothpaste [4-6]. Some studies showed that the prevalence of caries falls by up to $30 \%$ in patients who use fluoride-containing toothpastes, compared to those who brush without toothpastes or with toothpastes without fluoride $[4,5]$.

It is recommended to use toothpaste in children from the first tooth; the concentration and the quantity are the two parameters that change. Therefore, from the first tooth to two years old, it is recommended to use a toothpaste with at least 1000 ppm, twice daily and in an amount the size of a grain of rice; from two to six years, it is recommended to use the 
same toothpastes, but in a pea-sized amount; finally, over six years, it is recommended to use a toothpaste with at least 1450 ppm [6,7].

Toothpastes stay at the mouth for the 2 min of brushing and they stay for more time because rinsing is not recommended after regular brushing; thus, fluoride remains in the mouth (saliva and mucosa) for more time, and it will perform its remineralizing function for longer $[4,6,7]$. Some studies evidenced that the level of fluoride in saliva stays for more time than the two minutes of cleaning [8]. Moreover, it can remain $24 \mathrm{~h}$ after application, depending on its concentration [9], and in addition, the concentration in the mucosa is higher than in saliva [10]. Thus, toothpastes are in contact with human gingival fibroblasts for a long time compared to other oral materials [11-13]. On the basis of these reasons, some studies investigated the cytotoxicity of different toothpastes [14-16], finding that the toxicity varies according to the toothpastes' composition.

In a general, the composition of toothpastes is based on: fluorides, antiplaque agents, anti-malodor agents, anti-calculus agents, erosion prevention agents, excipients, abrasives, other noteworthy active ingredients, viscosity and rheology modifiers, humectants, sweeteners, coloring, preservatives, water, surfactants and other excipients [17]; some of them being responsible for the toxicity.

Accordingly, the present in vitro study aimed to compare the cytotoxicity of five different commonly used children's toothpastes: Oral B Kids +3 (Procter \& Gamble), Fluor Kin Calcium (Kin), PHB Junior (PHB), Colgate +3 (Colgate Palmolive) and Vitis Kids (Dentaid) on human gingival fibroblasts. The null hypothesis is that none of the toothpastes tested are biocompatible with human gingival fibroblasts.

\section{Materials and Methods}

\subsection{Preparation of Children's Toothpaste Eluates}

The toothpastes tested were five different commercially available children's toothpastes: Oral B Kids +3 , Fluor Kin Calcium, PHB Junior, Colgate +3 and Vitis Kids. The manufacturer's data, the composition, and the lot number of each of the materials tested are shown in Table 1.

Table 1. Children's toothpastes tested.

\begin{tabular}{|c|c|c|c|}
\hline Material & Manufacturer & Composition & Lot Number \\
\hline Oral B Kids +3 & $\begin{array}{c}\text { Procter \& Gamble Poligono } \\
\text { Industrial El Espartal, 1, } \\
\text { 03100, Xixona, } \\
\text { Alicante, Spain }\end{array}$ & $\begin{array}{l}\text { Aqua, Hydrated Silica, Cocamidopropyl Betaine, } \\
\text { Trisodium Phosphate, Aroma, Cellulose Gum, Sodium } \\
\text { Fluoride, Carbomer, Sodium Saccharin, Limonene, } \\
\text { Benzyl Alcohol, Sodium Benzoate, Cinnamal, } \\
\text { Polysorbate 80, CÑ } 42090 \text { (1450 ppm Fluoride) }\end{array}$ & 0213028870 \\
\hline Fluor Kin Calcium & $\begin{array}{c}\text { Laboratorios KIN SA Calle } \\
\text { Fuerteventura, 4-PLT BJ, } \\
\text { San Sebastian de los Reyes, } \\
\text { Madrid, Spain }\end{array}$ & $\begin{array}{l}\text { Aqua, Sorbitol, Glycerin, Hydrated Silica, Aroma, } \\
\text { Titanium Dioxide, Xanthan Gum, Xylitol, Sodium } \\
\text { Monofluorophosphate, Sodium Lauryl Sulfate, Sodium } \\
\text { Methylparaben, Calcium Glycerophosphate, Citric Acid, } \\
\text { Sodium Propylparaben, Potassium Acesulfame } \\
\text { (1000 ppm Fluoride) }\end{array}$ & $20 \mathrm{C} 09$ \\
\hline PHB Junior & $\begin{array}{l}\text { Laboratorios de Prevención } \\
\text { e Higiene Bucal, Castanyer } \\
\text { 25, 08022, Barcelona, Spain }\end{array}$ & $\begin{array}{c}\text { Aqua, Sorbitol, Silica, Glycerin, Titanium Dioxide, } \\
\text { Sodium Gluconate, Potassium Acesulfame, Sodium } \\
\text { Lauryl Sulfate, PEG-40, Hydrogenated Castor Oil, } \\
\text { Xanthan Gum, Sodium Fluoride, Sodium Saccharin, } \\
\text { Sodium Methylparaben, Tocopheryl Acetate, Lactic } \\
\text { Acid, Aroma (1000 ppm Fluoride) }\end{array}$ & M2005 \\
\hline
\end{tabular}


Table 1. Cont.

\begin{tabular}{|c|c|c|c|}
\hline Material & Manufacturer & Composition & Lot Number \\
\hline Colgate 3+ & $\begin{array}{l}\text { Colgate-Palmolive, } \\
\text { C/Quintanavides, } \\
\text { 19-Edificio 4. 28050, } \\
\text { Madrid, Spain }\end{array}$ & $\begin{array}{l}\text { Sorbitol, Aqua, Hydrated Silica, Xylitol, PEG-12, } \\
\text { Cellulose Gum, Benzyl Alcohol, Sodium Lauryl Sulfate, } \\
\text { Sodium Fluoride, Aroma (1000 ppm Fluoride) }\end{array}$ & (L)1007PL112C 1 \\
\hline Vitis Kids & $\begin{array}{l}\text { Dentaid Benimaclet, } 39 \\
46120 \text { Alboraia, } \\
\text { Valencia, Spain }\end{array}$ & $\begin{array}{l}\text { Aqua, Sorbitol, Silica, Glycerin, Xylitol, Sodium } \\
\text { Benzoate, Cellulose Gum, PEG-40, Hydrogenated } \\
\text { Castor Oil, Sodium Lauryl Sarcosinate, Propylene } \\
\text { Glycol, Sodium Fluoride, Sodium Saccharin, Benzoic } \\
\text { Acid, Mica, Titanium Dioxide, Tetrasodium EDTA, } \\
\text { Neohesperidin Dihydrochalcone, Aroma, CL16035 } \\
\text { (1000 ppm Fluoride) }\end{array}$ & R2015 \\
\hline
\end{tabular}

Eluates of these materials were prepared following ISO 10993-5 recommendations. Therefore, $0.2 \mathrm{~g}$ of each toothpaste was mixed with $1 \mathrm{~mL}$ of DMEM culture medium (Gibco, Thermo Fisher Scientific, Carlsbad, CA, USA), centrifuged at $4200 \mathrm{rpm}$, and the supernatant was collected and filtered. This conditioned medium was sterilized by exposure to ultraviolet light for two hours and used undiluted (1:1), half-diluted (1:2), and quarter-diluted (1:4) for the subsequent experiments.

\subsection{Isolation and Culture of Human Gingival Fibroblasts}

Human gingival fibroblasts were obtained from impacted tooth extraction $(n=10)$, following the Ethical Committee of the University of Murcia (ID: 2199/2018). All the individuals signed the consent form according to Helsinki Declaration Guidelines and were informed about the research project.

The excised gingival tissues were immediately digested for $2 \mathrm{~h}$ at $37^{\circ} \mathrm{C}$ with $3 \mathrm{mg} / \mathrm{mL}$ collagenase I (Sigma-Aldrich, St. Louis, MO, USA) and $4 \mathrm{mg} / \mathrm{mL}$ dispase II (Invitrogen, Waltham, MA, USA). Then, the cells were cultured in basal growth medium (Dulbecco's modified Eagle's medium (Invitrogen)), supplemented with 10\% fetal bovine serum (Invitrogen), 1\% GlutaMAX (Thermo Fisher Scientific) and 1\% penicillin/streptomycin (Invitrogen). The cells were passaged until they reached $80 \%$ confluency, and the cells from passages 2-4 were used for this study.

\subsection{MTT Assays}

Assessment of the metabolic activity of hGFs treated with the toothpaste eluates was performed using a colorimetric 3-(4,5-dimethylthiazol-2-yl)-2,5-diphenyltetrazolium bromide (MTT) assay, as previously described [12]. Briefly, hGFs were resuspended in complete growth medium $\left(w / o\right.$ red phenol) and plated at $1 \times 10^{4}$ cells/well in 96-well plates (control), or in complete growth medium at different dilutions $(1: 1,1: 2,1: 4)$ of each children's toothpaste and cultured for $2 \mathrm{~min}, 30 \mathrm{~min}, 6 \mathrm{~h}, 24 \mathrm{~h}$ or $72 \mathrm{~h}$ at $37{ }^{\circ} \mathrm{C}$. Then, MTT reagent (Sigma-Aldrich) at a final concentration of $1 \mathrm{mg} / \mathrm{mL}$ was added to the wells, incubated for $4 \mathrm{~h}$ at $37^{\circ} \mathrm{C}$ and solubilized with dimethyl sulfoxide (DMSO) (Sigma-Aldrich). Afterwards, the formazan production, directly proportional to the cell metabolic activity, was measured in a spectrophotometer (ELx800; Bio-Tek Instruments, Winooski, VT, USA) by the analysis of the absorbance at a wavelength of $570 \mathrm{~nm}$. Three separate experiments using hGFs isolated from three different donors were performed, each carried out in quintuplicate for each children's toothpaste and controls.

\subsection{Cell Cycle Analysis}

Cell cycle analysis, by measuring the DNA content, is a method that most frequently employs flow cytometry to distinguish cells in the different phases of the cell cycle. The hFGs were cultured with the different toothpaste extracts $(1: 1,1: 2,1: 4)$ for $24 \mathrm{~h}$. Then, the cells were collected and fixed in $70 \%$ ethanol and incubated with $40 \mu \mathrm{g} / \mathrm{mL}$ of propidium 
iodide (PI) and $200 \mu \mathrm{g} / \mathrm{mL}$ RNase for DNA content analysis. Fluorescence was measured with a FACScan Flow Cytometer (Becton Dickinson, San Jose, CA, USA) and the percentage of hFGs in the $G_{0} / G_{1}, S$ and $G_{2} / M$ phases was analyzed using Cell Quest (Sebring, FL, USA) and Modfit LT programs (Becton Dickinson, San Jose, CA, USA).

\subsection{Cell Cytoskeleton Staining}

Fluorescent phalloidin labeling was used to evaluate the organization of the F-actin fibers, as well as for possible changes in cell morphology. Briefly, $3 \times 10^{4} \mathrm{hGFs}$ were added on glass coverslips, allowed to adhere and spread, and cultured in complete growth medium alone (control) or in complete growth medium containing undiluted (1:1), or 1:2 or $1: 4$ dilutions of the different toothpaste eluates at $37^{\circ} \mathrm{C}$. After $72 \mathrm{~h}$, the glass coverslips were extensively washed with PBS at $37^{\circ} \mathrm{C}$, fixed in PBS containing $4 \%$ formaldehyde for $10 \mathrm{~min}$ and permeabilized with PBS containing $0.25 \%$ Triton X-100 (Sigma-Aldrich) for $5 \mathrm{~min}$. Afterwards, cells were stained with Invitrogen ${ }^{\mathrm{TM}}$ AlexaFluor ${ }^{\mathrm{TM}}$ 594-labeled phalloidin (Thermo Fisher Scientific) and 4,6-diamidino-2-phenylindole dihydrochloride (DAPI) (Thermo Fisher Scientific) at $\mathrm{r} / \mathrm{t}$ in for $30 \mathrm{~min}$, to detect cell F-actin filaments and nuclei, respectively. Representative images were acquired using a Leica TCS SP2 confocal microscope (Leica, Wetzlar, Germany). Three different images were captured in random fields for each material and dilution.

\subsection{Apoptosis/Necrosis Assays}

hGF viability after treatment with the different toothpaste eluates was evaluated by annexin-V-FITC and 7-AAD staining (BD Biosciences) following the manufacturer's instructions. Briefly, $3 \times 10^{4} \mathrm{hGFs}$ were cultured in complete growth medium alone (control) or in $1: 1,1: 2$ or $1: 4$ toothpaste dilutions at $37^{\circ} \mathrm{C}$ for $72 \mathrm{~h}$. The samples were analyzed in an LSR Fortessa X-20 flow cytometer (Becton Dickinson) within $1 \mathrm{~h}$ after staining. Finally, the percentages of live (unstained), early apoptotic (annexin-V-FITC positive), late apoptotic and necrotic (annexin-V-FITC and 7-AAD double-positive) cells were determined. Each condition was analyzed in triplicate.

\subsection{ICP-MS and Ion Chromatography}

Briefly, $2 \mathrm{~g}$ of toothpastes were mixed with $1 \mathrm{~mL}$ of DMEM culture medium and centrifuged at $4200 \mathrm{rpm}$. Afterwards, the supernatants were collected and filtered, and the proportion of calcium, potassium, magnesium, sodium, phosphorus, and silica released from each toothpaste was determined using ICP-MS (Agilent 7900 ICP-MS, Agilent, Santa Clara, CA, USA).

Fluoride concentration was analyzed using a Dionex ICS-2100 ion chromatograph (IC) with an AS19 column, using potassium hydroxide as the eluent.

\subsection{Statistical Analysis}

Each experimental condition was assayed three times and evaluated in three independent experiments. Data were expressed as the mean \pm standard deviation (SD). Data were analyzed by one-way analysis of variance (ANOVA) followed by Tukey's posthoc test for multiple comparisons, using GraphPad Prism software version 8.0.2 (GraphPad Software, San Diego, CA, USA); $p<0.05$ was considered to indicate a statistically significant difference.

\section{Results}

\subsection{MTT}

As shown in Figure 1, the metabolic activity of PHB Junior, Colgate and Fluor Kin were close to $0 \%$ in all concentrations, and at all the time points analyzed $(2 \mathrm{~min}, 30 \mathrm{~min}$, $6 \mathrm{~h}$ and $24 \mathrm{~h}$ ), showed significant differences compared to the control group $\left({ }^{* *} p<0.0001\right)$, suggesting a high cytotoxicity. However, Oral B showed an adequate cell metabolic activity $(100 \%)$ in all concentrations at 2 min. At longer times, undiluted Oral B exhibited null 
metabolic activity (0\%) at $30 \mathrm{~min}, 6 \mathrm{~h}$ and $24 \mathrm{~h}$, with significant differences compared to the control $(* * *<0.0001)$. Furthermore, at 1:2 and 1:4 dilutions of Oral B, the metabolic activity decreased when the dilution was lower and when the time increased. Finally, Vitis Kids showed good results at 1:2 and 1:4, at $2 \mathrm{~min}$ and $30 \mathrm{~min}$, but the metabolic activity decreased with time $(6 \mathrm{~h}$ and $24 \mathrm{~h})\left({ }^{* *} p<0.0001\right)$.
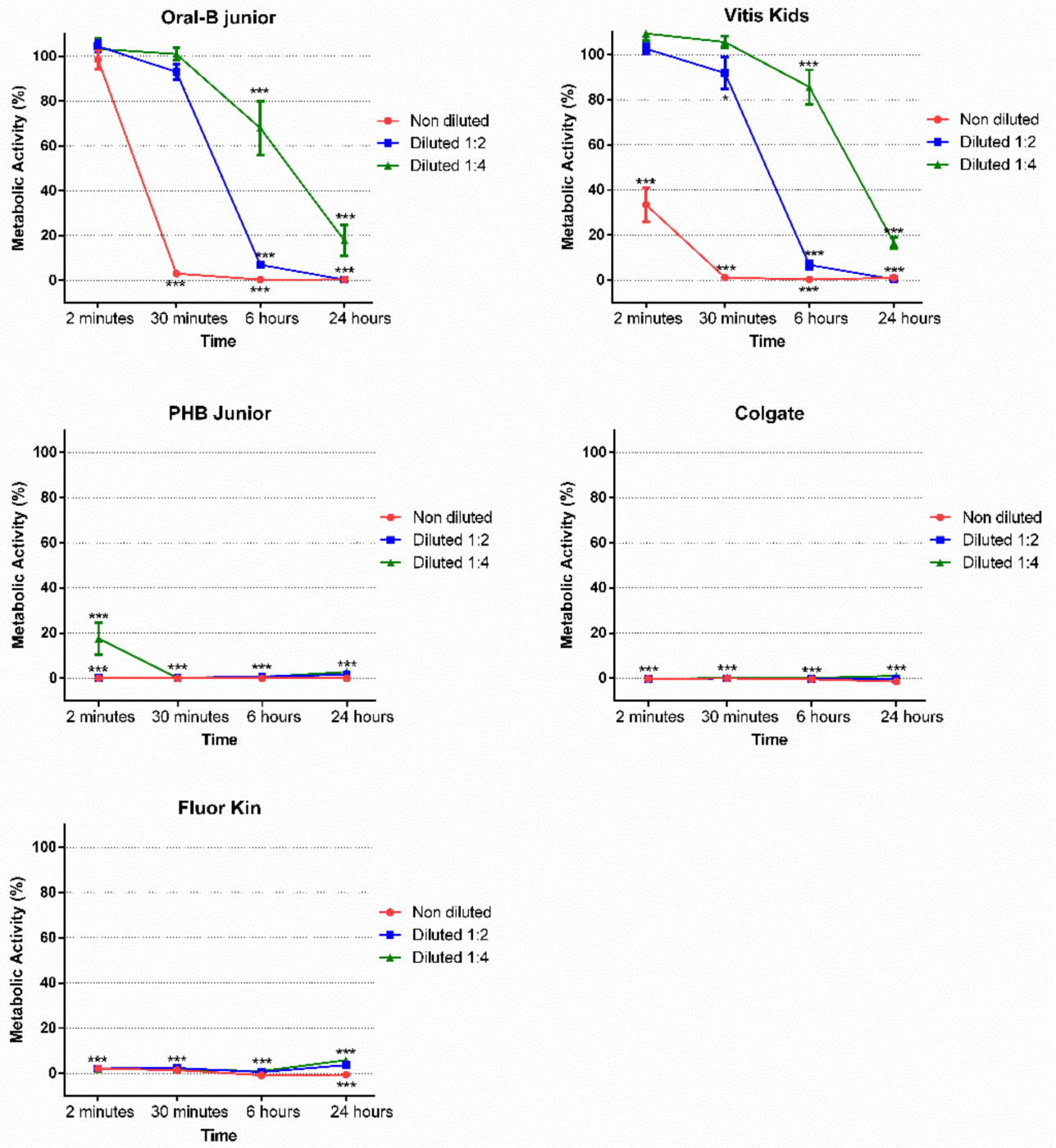

Figure 1. Metabolic activity of hGFs treated with different children's toothpaste concentrations (1:1, $1: 2,1: 4)$ for $2 \mathrm{~min}, 30 \mathrm{~min}, 6 \mathrm{~h}$ and $24 \mathrm{~h}\left({ }^{*} p<0.05,{ }^{* * *} p<0.001\right)$ according to one-way ANOVA and Tukey's post hoc test.

\subsection{Cell Cycle Analysis}

Cell cycle phase distributions are presented in Figure 2. Undiluted Oral B and Vitis Kids exhibited the majority of the cells in $\mathrm{G}_{0} / \mathrm{G}_{1}$ phase (67.63\% and $71.37 \%$, respectively); Vitis Kids had very few cells in $\mathrm{G}_{2} / \mathrm{M}$ phase $(0.98 \%)$ and some of them in $\mathrm{S}$ phase $(19.75 \%)$. Meanwhile, Oral B had more cells in $\mathrm{G}_{2} / \mathrm{M}$ phase $(24.81 \%)$ and less in $\mathrm{S}$ phase $(7.45 \%)$. 


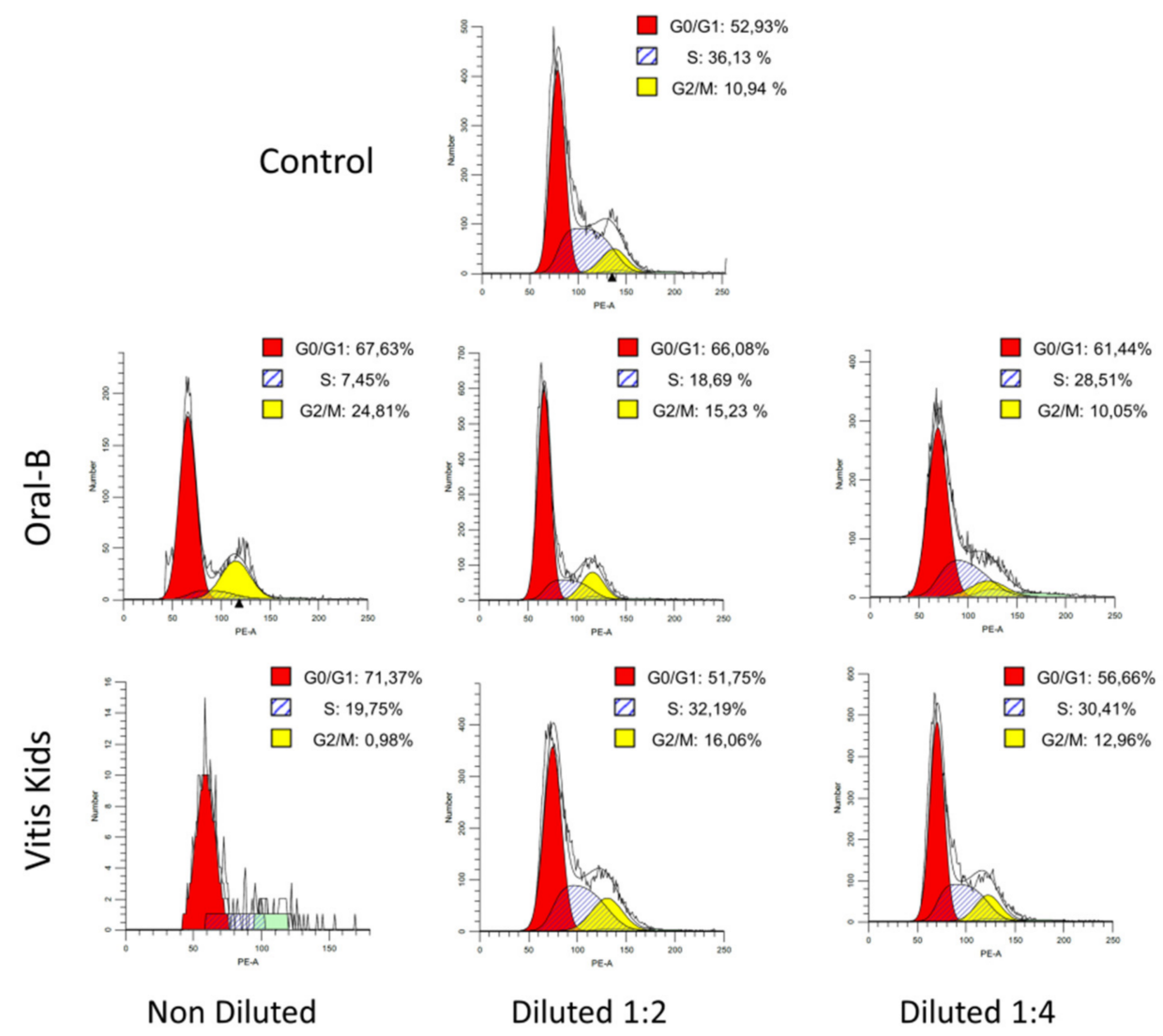

Figure 2. Cell cycle analysis of hGFs after exposure to different children's toothpaste concentrations $(1: 1,1: 2,1: 4)$. Histograms shown are representative of $n=3$ separate experiments.

On the other hand, 1:2 and 1:4 dilutions of Vitis Kids showed similar cell distribution in each phase, with $51.75 \%$ and $56.66 \%$ in $\mathrm{G}_{0} / \mathrm{G}_{1}$ phase, $32.19 \%$ and $30.41 \%$ in $\mathrm{S}$ phase and $16.06 \%$ and $12.96 \%$ in $\mathrm{G}_{2} / \mathrm{M}$ phase, respectively. Oral B showed the majority of the cells in $\mathrm{G}_{0} / \mathrm{G}_{1}$ phase $(66.08 \%$ and $61.44 \%$ ) in both concentrations (1:2 and $1: 4)$, followed by $S$ phase but with different concentrations $(18.69 \%$ and $28.51 \%)$ and finally, $\mathrm{G}_{2} / \mathrm{M}$ phase $(15.23 \%$ and $10.05 \%)$.

All the other toothpastes (Fluor Kin, PHB Junior and Colgate) had no results because all of the cells were dead after treatment.

\subsection{Cell Cytoskeleton Staining}

When hGFs were exposed to different toothpastes for $72 \mathrm{~h}$ (Figure 3), Oral B cells exhibited a morphology similar to those observed in the control in all the concentrations, with a high quantity and well-attached cells, and an evident actin cytoskeleton and fibroblastic morphology. Vitis Kids only showed cells with a morphology similar to the control and the Oral B groups at 1:2 and 1:4, whereas Colgate did not show any cells at any concentration. Finally, PHB Junior only showed some attached cells at 1:2 and 1:4, whereas Fluor Kin, at 1:4 dilution, displayed a considerably smaller number of attached cells with aberrant morphology. 


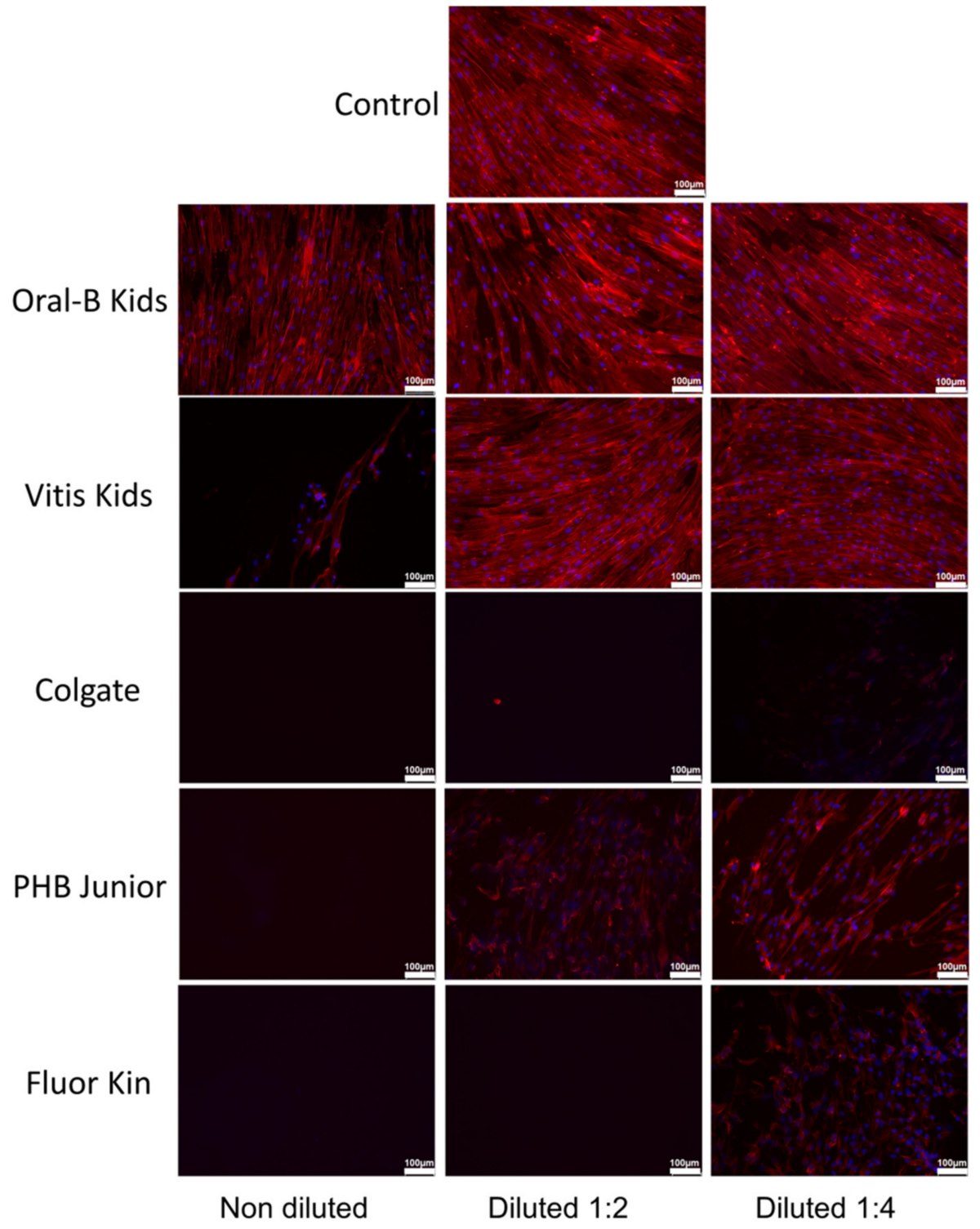

Figure 3. Morphological aspects and cytoskeleton F-actin fibers organization on hGF cultures exposed to different children's toothpastes by confocal fluorescence microscopy. F-actin fibers were stained with AlexaFluor ${ }^{\mathrm{TM}}$ 594-labeled phalloidin (red fluorescence), whereas cell nuclei were counterstained with DAPI (blue fluorescence). Scale bar: $100 \mu \mathrm{m}$.

\subsection{Apoptosis/Necrosis Assay}

Figure 4 shows the percentage of live and apoptotic/necrotic cells after treatment with different dilutions of children's toothpastes. Among all of them, Oral B showed a percentage of live cells higher than $92 \%$ in all the concentrations, and similar to that observed with the 1:2 and 1:4 concentrations of Vitis. Conversely, Colgate and Fluor Kin only showed $15-17 \%$ of live cells in all the concentrations analyzed $(1: 1,1: 2,1: 4)$, while PHB displayed an intermediate result, with $52 \%$ to $69 \%$ of live cells. 


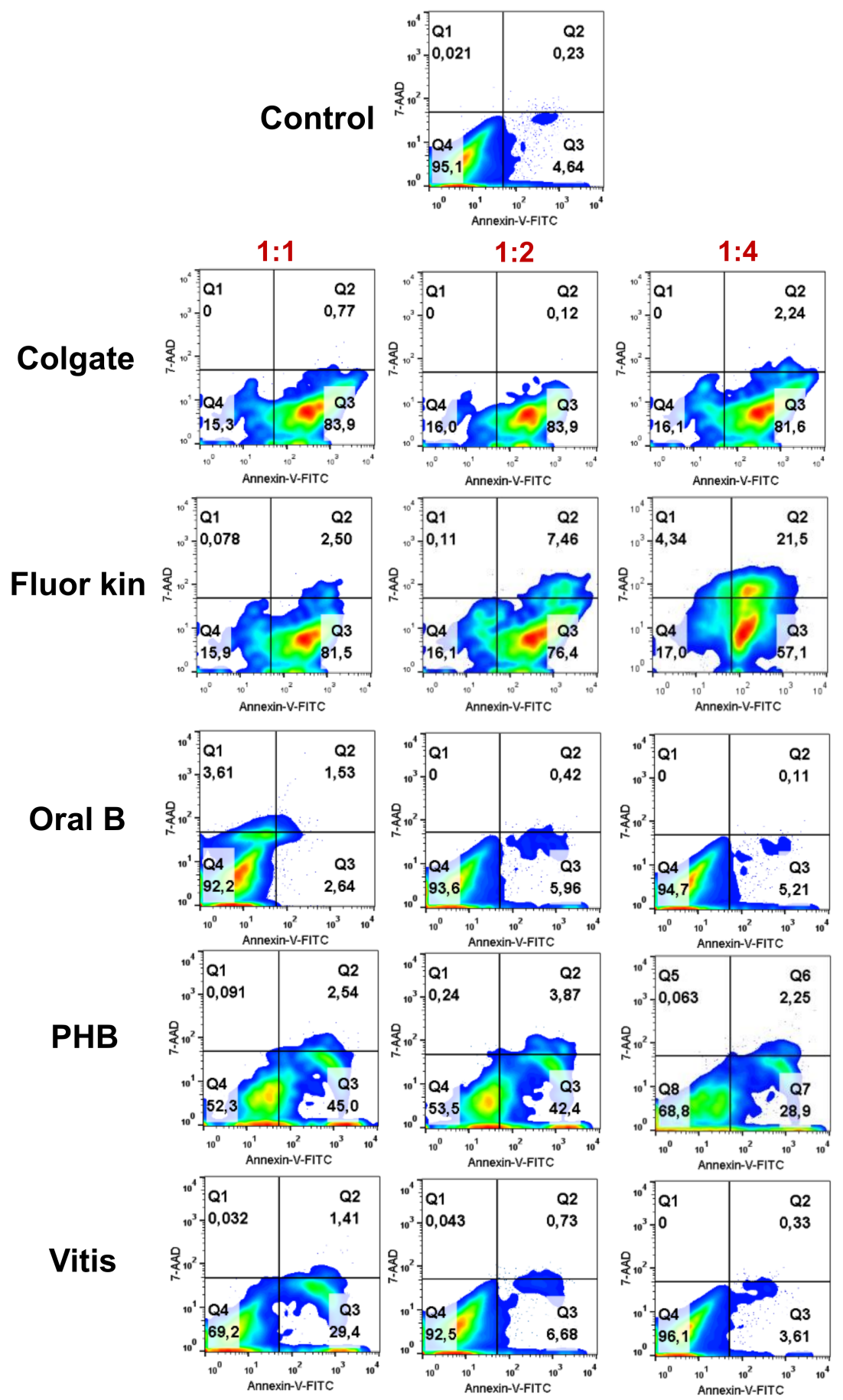

Figure 4. Flow cytometry analysis of cell apoptosis and necrosis induced by the different children's toothpaste concentrations on hGFs by annexin-V and 7-AAD staining. Numbers inside density plots represent percentages of live (Q4), early apoptotic (Q3), and late apoptotic and necrotic cells (Q1 and Q2) at different concentrations (1:1, 1:2, 1:4). Displayed dot plots are representative of three independent experiments performed in triplicate for each material.

\subsection{ICP-MS and Ion Chromatography}

ICP-MS analyzed the ion release as shown in Table 2. The results showed that Ca ion was only detected in Colgate and Fluor Kin, although it is not among the components of Colgate (Table 1). In addition, $\mathrm{K}$ ion was present in all the toothpastes, but in a low quantity, with the exception of PHB Junior which displayed 286.6 ppm; only PHB Junior and Fluor Kin had this element in their composition (Table 1). Mg ion was only found in Colgate, 
Fluor Kin and Vitis Kids, but in a low quantity, and it is not specified in the composition of any of the toothpastes. Na ion was detected in all the toothpastes, with higher levels of Na being found in Oral B (1002.6 ppm). P ion was present in all the toothpastes, with the higher levels detected in Oral B, followed by Fluor Kin. Finally, Si ion was present in all the toothpastes in moderate levels.

Table 2. ICP-MS results.

\begin{tabular}{|c|c|c|c|c|c|c|}
\hline & $\begin{array}{c}\text { Ca }(318.127 \mathrm{~nm}) \\
\text { ppm }\end{array}$ & $\begin{array}{c}\mathrm{K}(766.491 \mathrm{~nm}) \\
\text { ppm }\end{array}$ & $\begin{array}{c}\mathrm{Mg}(277.983 \mathrm{~nm}) \\
\text { ppm }\end{array}$ & $\begin{array}{c}\mathrm{Na}(588.995 \mathrm{~nm}) \\
\text { ppm }\end{array}$ & $\begin{array}{c}P(214.914 \mathrm{~nm}) \\
\text { ppm }\end{array}$ & $\begin{array}{c}\text { Si }(251.432 \mathrm{~nm}) \\
\text { ppm }\end{array}$ \\
\hline Colgate & 1.1 & 1.1 & 0.6 & 459.5 & 1.4 & 12.1 \\
\hline Fluor Kin & 13.8 & 11 & 0.8 & 576.2 & 270.2 & 5.9 \\
\hline PHB Junior & 0 & 286.6 & 0 & 640.1 & 5.4 & 20.6 \\
\hline Oral B Kids & 0 & 2.3 & 0 & 1002.6 & 334.8 & 4.6 \\
\hline Vitis Kids & 0 & 1.2 & 0.1 & 843.1 & 2.5 & 10.7 \\
\hline
\end{tabular}

The ion chromatography (Table 3) showed the bioavailable ionic fluoride delivered in the different toothpastes. Oral B showed the highest value with $230.42 \mathrm{mg} / \mathrm{L}$ of fluoride; meanwhile, Fluor Kin showed the lowest value with $22.91 \mathrm{mg} / \mathrm{L}$ of fluoride. The remaining toothpastes displayed a similar ion release.

Table 3. Ion fluoride release.

\begin{tabular}{cc}
\hline Toothpaste & Fluoride Concentration \\
\hline Colgate & $118.14 \pm 2.22 \mathrm{mg} / \mathrm{L}$ \\
\hline Oral B Kids & $230.42 \pm 5.56 \mathrm{mg} / \mathrm{L}$ \\
\hline Vitis Kids & $146.75 \pm 5.08 \mathrm{mg} / \mathrm{L}$ \\
\hline PHB Junior & $163.54 \pm 3.03 \mathrm{mg} / \mathrm{L}$ \\
\hline Fluor Kin & $22.91 \pm 3.00 \mathrm{mg} / \mathrm{L}$ \\
\hline
\end{tabular}

\section{Discussion}

In this study, we aimed to assess the cytocompatibility of five toothpastes indicated for use with children. Our findings evidenced different results between the toothpastes analyzed. Four of them were very cytotoxic (Fluor Kin Calcium, PHB Junior, Colgate +3 and Vitis Kids), whereas only Oral B +3 evidenced good biocompatibility results using hGFs as a cellular model.

In terms of cytotoxicity, the composition seems to have an important role. Nowadays, sodium lauryl sulfate (SLS) is the surfactant most used in toothpastes [17]. Cvikl et al. [15] and Birant et al. [16], who analyzed different children's toothpastes, concluded that all the toothpastes containing sodium lauryl sulfate (SLS) had the worst results, which was in concordance with another study, but using adult's toothpastes [18]. In addition, Tabatabaei et al. [11] analyzed the ingredients commonly used in toothpastes and agreed that SLS had the worst results. All of these results are in agreement with our findings, being that Oral B is the only toothpaste without SLS in its composition and with the best biocompatibility results. Interestingly, Vita Kids, that contained sodium lauryl sarcosinate instead of sodium lauryl sulfate, exhibited moderate cell viability rates. Therefore, more studies are necessary that analyze the influence of sodium lauryl sarcosinate in the biocompatibility of toothpastes.

Another commonly used surfactant is cocamidopropyl betaine (CAPB) [17]. It has been reported that the presence of CAPB only (without being mixed with another detergent) has been associated with adequate cell viability results [15], consistent with other cytotoxicity studies using adult's toothpastes [18]. This finding agrees with our results, since Oral B, which had the best results, is the only toothpaste with this surfactant in its composition. 
Conversely, Tabatabaei et al. [14] reported moderate cytotoxicity with CPAB. Thus, our results could be explained due to the low concentrations of CPAB in these toothpastes.

Sodium benzoate is used as a preservative in toothpastes. Its cytotoxicity was analyzed by Tabatabei et al. [11], who concluded that this component at standard concentration was not toxic for hGFs; among all the components analyzed, it caused the lowest cytotoxicity. These results agree with ours; this preservative is present in Oral B and Vitis Kids, which produced the best results. Paraben is another commonly used preservative which was analyzed that presented low cytotoxicity [14], which is in Oral B. In summary, all the components present in Oral B had the best results, which agrees with our results, being that Oral B is the most biocompatible children's toothpaste.

The ion chromatography analyzed the bioavailable ionic fluoride delivered in toothpastes. Oral B showed the highest value, being reasonable because it is the toothpaste with the higher concentration of fluoride (1450 ppm compared to $1000 \mathrm{ppm}$ in the other toothpastes), although it releases more than twice the fluoride ions than the others $(230.42 \mathrm{mg} / \mathrm{L})$; Levine et al. [19] concluded that the fluoride content is not the same as the bioavailable ionic fluoride, which agrees with our results because Fluor Kin displayed the lowest concentration $(22.91 \mathrm{mg} / \mathrm{L})$, around six times lower than Colgate, Vitis Kids and PHB, although it showed the same concentration in ppm compared to these other toothpastes (1000 ppm).

Oral B showed the highest concentration in ppm of fluoride. It also releases the highest amounts of fluoride ions, being the toothpaste with the highest biocompatibility of all the toothpastes analyzed in this study. This means that fluoride does not influence the cytotoxicity of toothpastes.

A limitation of this study is that we have not measured the fluoride ppm of the toothpastes, only the bioavailable ionic fluoride. If the ppm of Fluor Kin was wrong, it could explain why the bioavailable ionic fluoride was less. However, Perez-Silva et al. [20] analyzed the fluoride concentration in eleven toothpastes and the results agree with the manufacturers.

Given these results, it would be interesting to manufacture children's toothpastes with less cytotoxic surfactants and preservatives, since these are products that are used by growing children. In addition, future research is necessary to assess why the release of ions varies to ensure that all toothpastes release the required fluoride to prevent cavities.

\section{Conclusions}

Among all the toothpastes analyzed, Oral B had the best results in vitro in terms of biocompatibility. Future evaluations, both in vitro and in vivo, are required to confirm the biocompatibility of sodium lauryl sarcosinate and sodium lauryl sulfate containing toothpastes.

Author Contributions: Investigation and methodology, S.L.-G.; supervision, visualization, conceptualization, and data curation, F.J.R.-L.; supervision, visualization, conceptualization, and data curation, P.Á.-N.; conceptualization, formal analysis, project administration, supervision, validation, and writing — review and editing, M.P.P.-L.; investigation, methodology, project administration, resources, writing-original draft, and writing-review and editing D.G.-B. All authors have read and agreed to the published version of the manuscript.

Funding: The Spanish Cell Therapy Network (TerCel), RETICS subprograms of the I+D+I 2013-2016 Spanish National Plan, and project "RD16/0011/0001" funded by the Instituto de Salud Carlos III to JMM and co-funded by the European Regional Development Fund supported this work.

Institutional Review Board Statement: Not applicable.

Informed Consent Statement: Not applicable.

Data Availability Statement: The data presented in this study are available on request from the corresponding author.

Conflicts of Interest: The authors have declared no conflicts of interest. 


\section{References}

1. Pitts, N.B.; Zero, D.T.; Marsh, P.D.; Ekstrand, K.; Weintraub, J.A.; Ramos-Gomez, F.; Tagami, J.; Twetman, S.; Tsakos, G.; Ismail, A. Dental caries. Nat. Rev. Dis. Primers 2017, 3, 17030. [CrossRef]

2. Bawaskar, H.S.; Bawaskar, P.H. Oral diseases: A global public health challenge. Lancet 2020, 395, 185-186. [CrossRef]

3. Uribe, S.E.; Innes, N.; Maldupa, I. The Global Prevalence of Early Childhood Caries: A Systematic Review with Meta-analysis Using the WHO Diagnostic Criteria. Int. J. Paediatr. Dent. 2021, 31, 817-830. [CrossRef] [PubMed]

4. Horst, J.A.; Tanzer, J.M.; Milgrom, P.M. Fluorides and Other Preventive Strategies for Tooth Decay. Dent. Clin. N. Am. 2018, 62, 207-234. [CrossRef]

5. Walsh, T.; Worthington, H.V.; Glenny, A.M.; Marinho, V.C.; Jeroncic, A. Fluoride toothpastes of different concentrations for preventing dental caries. Cochrane Database Syst. Rev. 2019, 3, Cd007868. [CrossRef]

6. Pollick, H. The Role of Fluoride in the Prevention of Tooth Decay. Pediatr. Clin. N. Am. 2018, 65, 923-940. [CrossRef] [PubMed]

7. Toumba, K.J.; Twetman, S.; Splieth, C.; Parnell, C.; van Loveren, C.; Lygidakis, N. Guidelines on the use of fluoride for caries prevention in children: An updated EAPD policy document. Eur. Arch. Paediatr. Dent. 2019, 20, 507-516. [CrossRef] [PubMed]

8. Zamataro, C.B.; Tenuta, L.M.; Cury, J.A. Low-fluoride dentifrice and the effect of postbrushing rinsing on fluoride availability in saliva. Eur. Arch. Paediatr. Dent. 2008, 9, 90-93. [CrossRef]

9. Vincent, S.; Thomas, A.M. Fluoride Levels in Saliva and Plaque following the Use of High Fluoride and Conventional DentifricesA Triple Blinded Randomised Parallel Group Trial. Sci. World J. 2019, 2019, 1636209. [CrossRef] [PubMed]

10. Staun Larsen, L.; Baelum, V.; Richards, A.; Nyvad, B. Fluoride in Saliva and Oral Mucosa after Brushing with 1450 or 5000 ppm Fluoride Toothpaste. Caries Res. 2019, 53, 675-681. [CrossRef] [PubMed]

11. Lopez-Garcia, S.; Pecci-Lloret, M.P.; Garcia-Bernal, D.; Guerrero-Girones, J.; Pecci-Lloret, M.R.; Rodriguez-Lozano, F.J. Are Denture Adhesives Safe for Oral Cells? J. Prosthodont. 2021, 30, 65-70. [CrossRef]

12. López-García, S.; Pecci-Lloret, M.P.; Pecci-Lloret, M.R.; Guerrero-Gironés, J.; Rodríguez-Lozano, F.J.; García-Bernal, D. Topical fluoride varnishes promote several biological responses on human gingival cells. Ann. Anat. 2021, 237, 151723. [CrossRef]

13. López-García, S.; Guerrero-Gironés, J.; Pecci-Lloret, M.P.; Pecci-Lloret, M.R.; Rodríguez-Lozano, F.J.; García-Bernal, D. In Vitro Biocompatibility of CPP-ACP and Fluoride-containing Desensitizers on Human Gingival Cells. Oper. Dent. 2021. [CrossRef]

14. Tabatabaei, M.H.; Mahounak, F.S.; Asgari, N.; Moradi, Z. Cytotoxicity of the Ingredients of Commonly Used Toothpastes and Mouthwashes on Human Gingival Fibroblasts. Front. Dent. 2019, 16, 450-457. [CrossRef] [PubMed]

15. Cvikl, B.; Lussi, A.; Moritz, A.; Gruber, R. Dentifrices for children differentially affect cell viability in vitro. Clin. Oral. Investig. 2017, 21, 453-461. [CrossRef] [PubMed]

16. Birant, S.; Duran, Y.; Gokalp, M.; Akkoc, T.; Seymen, F. Effects of different detergent-containing children's toothpastes on the viability, osteogenic and chondrogenic differentiation of human dental periodontal ligament stem cells and gingival stem cells in vitro. Tissue Cell 2021, 72, 101538. [CrossRef] [PubMed]

17. Lippert, F. An introduction to toothpaste-Its purpose, history and ingredients. Monogr. Oral. Sci. 2013, 23, 1-14. [CrossRef]

18. Cvikl, B.; Lussi, A.; Gruber, R. The in vitro impact of toothpaste extracts on cell viability. Eur. J. Oral. Sci. 2015, 123, 179-185. [CrossRef] [PubMed]

19. Levine, R.S. Fluoride in toothpaste-Is the expressed total fluoride content meaningful for caries prevention? Br. Dent. J. 2020, 228, 795-799. [CrossRef]

20. Pérez-Silva, A.; Cury, J.A.; Martínez-Beneyto, Y.; Serna-Muñoz, C.; Cabello Malagón, I.; Ortiz-Ruiz, A.J. Total and soluble fluoride concentration in children's toothpastes in Spain. Rev. Esp. Salud Publica 2021, 95, e202104050. 